\title{
Coenopopulation structure of some high- mountain Nepeta species (serias Densiflora) in Central Asia
}

\author{
Alexey Yu. Astashenkov* \\ Central Siberian Botanical Garden of the SB RAS, Zolotodolinskaya Str., 101, Novosibirsk, 630090, \\ Russia
}

\begin{abstract}
The analysis of coenopopulations of high-mountain Nepeta ser. Densiflorae from Central Asia is conducted. It is established that changes in the peaks of the ontogenetic spectrum from centered to double-peak centered reflect change of the biomorph from tap-root caudex to longrhizome-tap-root (caudex). The biomorph transformation directs at a gradient of changing environmental conditions: from cryoxerophitic to mesophitic habitats.
\end{abstract}

\section{Introduction}

In the process of evolution, the plants of high-mountainous belts produced various mechanisms of adaptations, the combination of which provided them with a steady modern existence. Group of such plants includes most species of the genus Nepeta from the Lamiaceae family. Perennial Nepeta have mainly endemic areas associated with alpine orogenesis, which influenced on their distribution and evolutionary development in the highlands of Central Asia. A comprehensive analysis carried out at various levels of the organization makes it possible to identify phylogenetic relationships and the main directions of evolutionary transformations at the population, species, and supraspecific (within closely related groups) levels.

The population-ontogenetic approach $[1,2]$, based on an assessment of the organismic and population levels and widely used in modern biology, makes it possible to determine the state of natural coenopopulations (CP) under various ecological-phytocoenotic conditions [3]. Population analysis of the Nepeta species and search for relationships between the elements of the morph and phytocoenotic environment were not conducted.

The purpose of the work is to identify the features of the population structure of some species of Nepeta. High-altitude Nepeta of different biomorphs, the taxa of which are united by a related group of the polymorphic series Densiflorae Pojark., were chosen as objects of study.

* Corresponding author: astal@bk.ru 


\section{Material and methods}

We used classical population-ontogenetic approaches. When studying ontogenesis, the concept of its discrete description was adopted [4-6]. The morphological study of the individuals was conducted both in the field and in the laboratory - on a fixed (herbarium) material (mainly). Ontogenetic spectra of coenopopulations were built on the basis of recording individuals on 25 sites of $1 \mathrm{~m}^{2}$ in size, laid in a regular way on transects $1 \mathrm{~m}$ wide in each coenosis. An individual (genet) and partial formations (ramet) are taken for the counting unit. The characteristic of ontogenetic structure of coenopopulations is given according to generally accepted methods $[1,2]$. The classification of "delta-omega" by L.A. Zhivotovsky [7] was used for determine the type of coenopopulation. The following demographic indicators: $\Delta-$ age index [5] and $\omega$ - efficiency index were taken [7]. Ecological density was established on the basis of the number of individuals per inhabited space unit (ind. $\left./ \mathrm{m}^{2}\right)[8]$.

\section{Results and discussion}

N. kokamirica Regel - Tash-Shan-Dzungar-Kashgar herbaceous, caudex-forming perennial. The species grows on stony and gravelly mountain slopes, often on mobile scree substrates. It enters into the composition of the vegetation from the upper forest to the alpine zone [9]. The material was collected on the southern macroslope of the Dzungarian Alatau: Koksu Range, the gorge of the Burkhan river, semi-fixed loess-gravel scree, the upper border of the sub-alpine belt - a primitive plant aggregation of prostrate juniper stand (Juniperus pseudosabina Fisch. et C. Mey.). The spatial distribution of individuals at survey sites in the absence of phytocoenotic pressure has uneven group arrangement $-\min 1-2 \mathrm{ind} . / \mathrm{m}^{2}$, max 15-17 ind. $/ \mathrm{m}^{2}$. Individuals by local groups are concentrated along the upper edge of the axial part of the mountain slope in an open area surrounded by J. pseudosabina. The density of individuals in the CP was 5.2 ind./m2. Ontogenetic spectrum is centered, with an absolute maximum for mature generative plants. That type of spectrum is associated with the duration of this ontogenetic state. According to the classification of L. A. Zhivotovsky [7], the coenopopulation is aging: the age index $(\Delta)$ is 0.56 , the efficiency $(\omega)-0.65$. The obtained values reflect the high number of old generative plants and individuals of the postgeneration period. Nevertheless, the state of the studied CP, with high values of mature generative plants, can be characterized as normal, stable.

N. pulchella Pojark. - short-rhizome-tap-root (caudex) herbaceous perennial. Endemic of the Talas Alatau (Western Tien Shan). It grows in the composition of meadow and herbgrass-meadow coenoses on the northern macroslope of the ridge from the middle mountains to the subalpine belt [9]. The CP was studied in the Ulken-Kaindy gorge in the highlands. A single-peaked centered ontogenetic spectrum is formed in this CP. That type is associated with the continuous development of the individuals in the generative period, which coincides with the time of formation of the short rhizome. Particulation of the bush and the formation of long-lived ramet also influence on the delay in the rate of development of individuals. A significant proportion of old generative individuals are due to the repartitioning of the daughter ramet, which also leads to extended ontogenesis. $\mathrm{CP}$ is transition to mature: $\Delta-0.50, \omega-0.65$. Ecological density is $3.9 \mathrm{ind} . / \mathrm{m}^{2}$.

$N$. densiflora Kar. et Kir. - long- rhizome-tap-root (caudex) herbaceous perennial, distributed in the southern part of Gorny Altai. The border of the distribution is limited to Mongolia and East Kazakhstan. The species is confined to the mesophilic highlands of the alpine mountain belt. It includes in the composition of rarefied plant aggregation of screes and rocky mountain slopes [9]. The material was collected on the plain part of the Narym Range in the headwaters of the river Jajdak in the erozion sleeve of a temporary 
watercourse embedded in Alchemilla meadow The spatial distribution of individuals in the absence of phytocenotic influence has an uneven group arrangement from 2 to 19 ind. $/ \mathrm{m}^{2}$.The individuals concentrated along the edges of the temporary water flow sleeve. The density of individuals averaged 3.8 ind./m2. Ontogenetic spectrum is two-vertex centered. The absolute maximum in the spectrum turned out to be on juvenile individuals, the second - on the mature ones. A significant proportion of young individuals is associated with vegetative and seed regeneration. Nevertheless, the distribution of ontogenetic groups in $\mathrm{CP}$ reflects the characteristic ontogenetic spectrum of perennial plants of the root-root biomorph [2]. The CP according to the classification of L.A. Zhivotovsky is young: $\Delta-$ $0.24, \omega-0.46$.

\section{Conclusion}

An analysis of the ontogenetic structure of the coenopopulations of studied alpine species showed a vector of change in the ontogenetic structure associated with a change in the biomorph. The rearrangement of the ontogenetic spectrum peaks from centered to doubletop centered reflects the change of biomorph from tap-root caudex to long- rhizome-taproot (caudex) and directs in a gradient of changing environmental conditions from cryoxerophilic to mesophilic habitats. Various mechanisms of self-maintenance of the studied species CP determine their sustainable development in the plant communities of Central Asia.

The work was carried out according to the draft State assignment of the Central Siberian Botanical Garden of the Siberian Branch of the Russian Academy of Sciences No. AAAAA17-117012610053-9.

\section{References}

1. Plant coenopopulations: general terms and structure (M, Nauka, 1976)

2. Plant coenopopulations: basic concepts and structure (M, Nauka, 1988)

3. L.B. Zaugol'nova, Structure population of seed plants and related monitoring problems, Diss. (St. Petersburg, 1994)

4. T.A. Rabotnov, Tr. Bot. Inst., Akad. Nauk SSSR, 6, 3 (1950)

5. A.A. Uranov, Biol. Sciences, 2 (M,1975)

6. L.A. Zhukova, Population Life of the Meadow Plants (Yoshkar-Ola, Lanar, 1995)

7. L.A. Zhivotovsky, Rus. J. Ecol., 1 (2001)

8. Yu. Odum, Ecology, 2 (M, Nauka, 1986)

9. Flora of the Soviet Union, 20 (M.-L., Nauka, 1954) 